
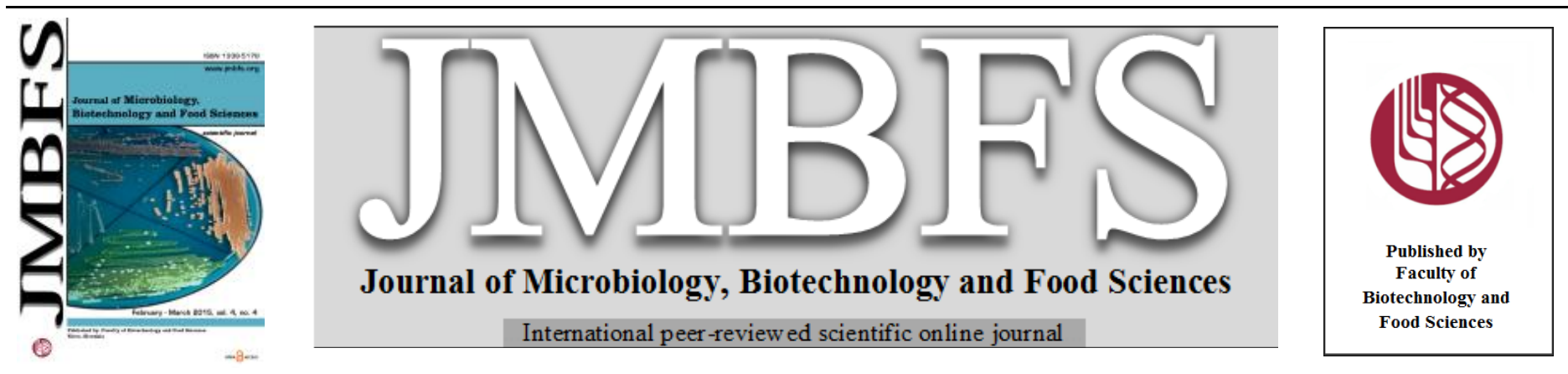

\title{
MOLECULAR CLONING AND CHARACTERIZATION OF NOVEL THERMOSTABLE LIPASE FROM SHEWANELLA PUTREFACIENS AND USING ENZYMATIC BIODIESEL PRODUCTION
}

\author{
Fahri Akbas $*^{1}$, Kaifee Arman ${ }^{2}$, Zeynep Aydin Sinirlioglu ${ }^{3}$, Deniz Sinirlioglu ${ }^{4}$ \\ Address(es): \\ ${ }^{1}$ Medical Biology Department, Bezmialem University, 34080, Fatih, Istanbul, Turkey. \\ ${ }^{2}$ Department of Medical Biology and Genetics, Faculty of Medicine, Gaziantep University, 27310, Sahinbey, Gaziantep,Turkey. \\ ${ }^{3}$ Department of Genetics and Bioengineering, Faculty of Engineering, Fatih University, 34500, Buyukcekmece, Istanbul, Turkey. \\ ${ }^{4}$ Department of Chemistry, Faculty of Arts and Science, Fatih University, 34500, Buyukcekmece, Istanbul, Turkey.
}

*Corresponding author: fahriakbas@gmail.com

doi: 10.15414/jmbfs.2015.4.4.297-300

\section{ARTICLE INFO}

Received 22.9. 2014

Revised 3. 11. 2014

Accepted 27. 11. 2014

Published 1. 2. 2015

Regular article

open $\partial_{\text {ACCESS }}$

\begin{abstract}
A novel thermostable lipase from Shewanella putrefaciens was identified, expressed in Escherichia coli, characterized and used in biodiesel production. Enzyme characterization was carried out by enzyme assay, SDS-PAGE and other biochemical reactions. The recombinant lipase was found to have a molecular mass of $29 \mathrm{kDa}$ and exhibited lipase activity when Tween 80 was used as the substrate. The purified enzyme showed maximum activity at $\mathrm{pH} 5.0$ and at $80^{\circ} \mathrm{C}$. The recombinant lipase was used for the transesterification of canola oil and waste oil. The enzyme retains $50 \%$ of its activity at $90^{\circ} \mathrm{C}$ for 30 minutes. It is also able to retain $20 \%$ of its activity even at $100{ }^{\circ} \mathrm{C}$ for 20 minutes. These properties of the obtained new recombinant thermostable lipase make it promising as a biocatalyst for industrial processes.
\end{abstract}

Keywords: Cloning, lipase, thermostable, Shewanella putrefaciens, biodiesel production

\section{INTRODUCTION}

Lipase (EC 3.1.1.3) is a kind of lipolytic enzyme, which is known to catalyze the hydrolysis of long-chain triglycerides. Microbial lipases are known to have diversity in their properties and substrate specificities, which further improve their biotechnological importance (Mhetras et al., 2009). Lipases are used to hydrolyze ester bonds of a variety of nonpolar substrates at high activity, stereoselectivity, and regioselectivity. Furthermore, they catalyze different amide and ester bonds formation in nonpolar solvents. The reaction can be designed and optimized to get a wide range of novel products. This can be done by making changes in substrate structure, additives, water activity, solvent, temperature, pressure and the biocatalyst itself. Selection of lipase being used in each application is based on its activity, stability and selectivity (Dizge $\boldsymbol{e t}$ al., 2009; Ebrahimpour et al., 2011; Hasan et al., 2006). They are widely used in the dairy and oleo chemical industries, in the synthesis of structured triglycerides, surfactants, pharmaceuticals and agrochemicals, and in polymers and household detergents (Hasan et al., 2006). Extracellular lipases are produced by a variety of microorganisms, including fungi (Cardenas et al., 2001) and bacteria (Eggert et al., 2002; Rashid et al., 2001; Yumoto et al., 2003). Lipases of microbial origin represent the most extensively used class and are receiving increasing attention due to their relative ease of production and potential applications in biotechnology (Shi et al., 2010; Bornscheuer et al., 2002; Schmid and Verger, 1998; Shibatani et al., 2000).

The important requirements for industrial application of enzymes is thermal stability. Although many lipases have already been studied, the requirement for new lipases with more improved thermal stability and substrate specificity is still an important field of research (Gutarra et al., 2009; Haki and Rakshit, 2003). As compared to mesophilic enzymes thermostable enzymes show higher resistance to chemical denaturants and are able to withstand higher substrate concentrations. These thermostable enzymes catalyze the reactions at higher process rates due to a decrease in viscosity and an increase in diffusion coefficient (Ebrahimpour et al., 2011). Therefore, thermostable lipases have got wide spread interest for potential application in the detergent, pharmaceutical, dairy, oil and fat industries due to their extreme stability at high temperatures and in organic solvents (Emtenani et al., 2013). So thermostable lipase also catalyzed biodiesel production has received attention due to several advantages such as mild reaction conditions, low energy consuming, and environment friendly (Arai et al., 2010; Dwiarti et al., 2010; Yan et al., 2011).
The aim of this work is to obtain novel thermostable lipase gene from Shewanella putrefaciens. The lipase gene from Shewanella putrefaciens was not defined in the GenBank database and the biochemical characterization of the purified enzyme from Shewanella putrefaciens has yet not been reported the subject of any study which may be a good contribution to GenBank database especially including lipase gene from Shewanella putrefaciens. In this contribution, firstly, the lipase gene was cloned, then, soluble expression was obtained and used biodiesel production. The obtained genes were characterized with using different parameters such as the effects of $\mathrm{pH}$ and temperature on the enzyme activity. Also, other biochemical characterizations were carried out. Therefore, this is the first report related to Shewanella putrefaciens lipase so far. A new bacterial lipase gene with industrial usage is likely to be obtained after further studies.

\section{MATERIAL AND METHODS}

\section{Chemicals and microorganisms}

All the chemicals and reagents were analytical grade and were purchased from commercial sources. Restriction endonucleases, other modifying enzymes and DNA polymerase were obtained from Thermo (USA). Shewanella putrefaciens was purchased from ATCC (USA) number of 8071. E. coli XL-1 Blue was used as the host for recombinant plasmids. The pET-28a (Novagen, Madison, WI, USA) was used as an expression vector to produce the target protein. E.coli BL21 (DE3-pLysS, Novagen) was used as the host for expression of lipase gene under the control of the T7 promoter. E. coli transformants were grown at $37{ }^{\circ} \mathrm{C}$ in Luria-Bertani (LB) broth and the LB medium was supplemented with $100 \mu \mathrm{g} / \mathrm{mL}$ kanamycin.

\section{Isolation and cloning of the lipase gene}

Genomic DNA isolation from Shewanella putrefaciens was performed using a High Pure PCR Template preparation kit (Roche, Germany), according to the manufacturer's instructions. In order to amplify the lipase gene of Shewanella putrefaciens, a nested PCR strategy was used. Suitable forward and reverse primers were designed which including the appropriate restriction enzyme site at the $5^{\prime}$ end. The PCR product was purified and then digested with EcoRI and HindIII enzyme and subsequently cloned into the expression vector pET28a (Novagen, USA) that had been previously digested with the same enzymes. 


\section{Expression of the lipase gene and purification of the recombinant protein}

The lipase gene was cloned in pET28a plasmid vector and transformed into E.coli BL21 (DE3, pLysS) cells for expression. The E.coli cells transformed with this plasmid and plated on a LB agar containing $100 \mu \mathrm{g} / \mathrm{ml}$ kanamycin. The transformat was grown in a $10 \mathrm{ml}$ flask containing $5 \mathrm{ml} \mathrm{LB}$ medium supplemented with $100 \mu \mathrm{g} / \mathrm{ml}$ kanamycin at $37^{\circ} \mathrm{C}$ shaking at speed of $250 \mathrm{rpm}$ overnight. The next day, a 1:100 dilution overnight culture was put into $50 \mathrm{ml}$ flask containing $20 \mathrm{ml} \mathrm{LB}$ without antibiotic. After reaching to 0.6 optical density at $600 \mathrm{~nm}$, cells were induced with $1 \mathrm{mM}$ IPTG (isopropyl- $b$-D-thiogalactoside) to induce the target protein expression. After incubation at $37^{\circ} \mathrm{C}$ for $4 \mathrm{~h}$ with shaking at $250 \mathrm{rpm}$, cells were harvested by centrifugation $(8,000 \times \mathrm{g}$ for $20 \mathrm{~min}$ a $4^{\circ} \mathrm{C}$ ) and washed twice with $50 \mathrm{mM}$ cold potassium phosphate buffer $(\mathrm{pH} 7.6)$ and the cell pellet was stored at $-20^{\circ} \mathrm{C}$ for later purification. All purification steps were performed according to the instruction of B-PER 6xHis Fusion Protein Purification Kits (Thermo, USA) and previous study (Sinirlioglu et al., 2013) Shortly, the cells were resuspended in $10 \mathrm{~mL}$ B-PER Reagent by either vortexing or pipetting up and down for homogenous suspension. The mixture was gently shaken at room temperature for 10 minutes. Lysate was centrifuged at $14,000 \times \mathrm{g}$ for $15 \mathrm{~min}$ to remove debris then the supernatant was collected in a new tube The column was prepared by adding $10 \mathrm{ml}$ of B-PER Reagent. The column was loaded with prepared extract and then washed with a wash buffer. The bound protein was eluted with elution buffer. The purity of the enzyme in the eluted fractions was checked by $\% 10$ SDS-PAGE. Protein concentration was determined by the Bradford method (Zhu et al.,2012) and bovine serum albumin was used as standard for calibration. Enzyme samples were stored at $-20^{\circ} \mathrm{C}$ until further use.

\section{Sequence analysis of lipase enzyme}

The DNA sequence analysis, enzyme characteristics and multiple sequence analysis was performed using the CLC-BIO main workbench like previous study (Sinirlioglu et al., 2013).

\section{Enzyme assay}

Free lipase activity was determined using Tween 80 as the substrate. The activity with Tween 80 as substrate was measured spectrophotometrically at $450 \mathrm{~nm}$ using $1 \%(w / v)$ Tween 80 in $20 \mathrm{mM}$ Tris- $\mathrm{HCl}(\mathrm{pH} \mathrm{7})$, containing $80 \mathrm{mM} \mathrm{CaCl}$ After the addition of the enzyme, the increase in absorbance was monitored as function of time. The increase in absorbance was the result of increasing turbidity of the in situ formed calcium oleate. Lipase activity were monitored UV-Vis Spectrophotometer. The reaction mixture which contained $500 \mu$ Tris-HC buffer, $200 \mu \mathrm{l}$ Tween 80 solution $(1 \% \mathrm{w} / \mathrm{v}), 200 \mu \mathrm{CaCl}_{2}$ solution $(80 \mathrm{mM})$ and $100 \mu \mathrm{l}$ enzyme, loaded into spectrophotometer and measured at $450 \mathrm{~nm}$ for 20 minutes of reaction time at room temperature. One unit $(U)$ of lipase activity was defined as $1.0 \mu \mathrm{mol}$ of product formed per minute under the assay conditions.

\section{Characterization of lipase enzyme}

The influence of temperature on lipase activity was studied spectrophotometrically. The reaction buffer contained $500 \mu \mathrm{l}$ Tris- $\mathrm{HCl}$ buffer, $200 \mu \mathrm{l}$ Tween 80 solution $(1 \% \mathrm{w} / \mathrm{v}), 200 \mu \mathrm{CaCl}_{2}$ solution $(80 \mathrm{mM})$ and $100 \mu \mathrm{l}$ enzyme. The effect of temperature on lipase activity was determined by incubating reaction buffer at various temperatures ranging $30^{\circ} \mathrm{C}$ to $100^{\circ} \mathrm{C}$. The influence of $\mathrm{pH}$ on lipase activity was also studied spectrophotometrically. The $\mathrm{pH}$ dependence was determined with Tween80 solution $(1 \% \mathrm{w} / \mathrm{v})$ as the substrate. The reaction buffer contained $500 \mu \mathrm{l}$ Tris-HCl buffer, $200 \mu \mathrm{l}$ Tween 80 solution $(1 \% \mathrm{w} / \mathrm{v}), 200 \mu \mathrm{C} \mathrm{CaCl} 2$ solution $(80 \mathrm{mM})$ and $100 \mu \mathrm{l}$ enzyme. $\mathrm{pH}$ of the reaction buffer was adjusted from 2 to 10 using $50 \mathrm{mM}$ glycine $\mathrm{HCl}$ buffers (pH 2.0 to 3.0 ), $50 \mathrm{mM}$ sodium acetate buffers ( $\mathrm{pH} 4.0$ to 5.0 ), $50 \mathrm{mM}$ sodium phosphate buffers (pH 6.0 to 7.0 ) and $2 \mathrm{M} \mathrm{NaOH}$ (pH 8.0 to 10.0). The enzyme stability against $\mathrm{pH}$ was determined by measuring the activities of enzyme after incubation at $4^{\circ} \mathrm{C}$ for $1 \mathrm{~h}$ in the buffers. Thermostability was determined by incubating at various temperatures $\left(30-100^{\circ} \mathrm{C}\right)$ at $\mathrm{pH} 5.0$ for $30 \mathrm{~min}$. The enzymatic assays were carried out under defined enzyme assay conditions. Al characterizations were performed triplicate for both $\mathrm{pH}$ and temperature effects.

\section{Effect of metal ions and chemical agents}

The effect of metal ions was determined by detecting the residual activity after incubating enzyme solution containing $5 \mathrm{mM}$ and $10 \mathrm{Mm}$ various metal ions at $80{ }^{\circ} \mathrm{C}$ for $1 \mathrm{~h}$. The sample without metal ions was taken as control. Effect of chemical agents was determined by comparing the residual activity after incubating lipase solution containing $5 \mathrm{mM}$ and $10 \mathrm{mM}$ chemical agents at $80{ }^{\circ} \mathrm{C}$ for $1 \mathrm{~h}$. The enzyme solution containing distilled water instead of chemical agents was taken as control.

\section{Transesterification reaction (biodiesel production)}

The transesterification reactions were carried out in a $50 \mathrm{ml}$ screw-capped vessel and heated to $65^{\circ} \mathrm{C}$ in a shaking incubator in $150 \mathrm{r} / \mathrm{min}$. The compositions of the reaction mixtures were $15 \mathrm{~g}$ of canola oil or waste oil, $100 \mathrm{IU}$ recombinant lipase and methanol (a 1:4 molar ratio of oil/methanol). After a $24 \mathrm{~h}$ reaction, $100 \mu$ sample was taken from the reaction mixture and centrifuged to obtain the upper layer. Methyl heptadecanoate which served as the internal standard and an aliquot of the upper layer were measured and mixed thoroughly for GC analysis to determine fatty acid methyl esters (FAMEs) and glycerides content. For the time course studies, an aliquot of $100 \mu 1$ of reaction medium was taken at various time intervals and was diluted in n-heptane for GC analysis. The methyl ester contents of reaction mixture were measured on a gas chromatograph (Agilent Technologies Model $6890 \mathrm{~N}$ ). Helium was used as carrier gas with a flow rate of $1.2 \mathrm{ml} / \mathrm{min}$.

\section{RESULTS AND DISCUSSION}

\section{Sequence analysis and molecular characterization of the lipase from Shewanella putrefaciens}

Using the primer pair of F- (5'-AGAATTCATGAATTATGTTTCCTCAG-3') and R- (5'-TTAAGCTTTTGGCACATTACCTTGC-3'), 896-bp open reading frame (ORF) was amplified from the genomic DNA of Shewanella putrefaciens The nucleotide sequence of lipase gene from Shewanella putrefaciens was not defined in the GenBank database and the biochemical characterization of the purified enzyme from Shewanella putrefaciens has yet not been reported the subject of any study. Gene for cloning were selected which encodes a putative lipase protein with 294 amino acids. The predicted molecular weight was $29 \mathrm{kDa}$. A sequence analysis with a BLAST search in the database NCBI showed that the putative lipase gene from Shewanella putrefaciens was a member of the PGAP1 super family protein and also the metX super family which belongs to the $\alpha, \beta$ fold hydrolase domain. The conserved pentapeptide Gly-X-Ser-X-Gly in most microbial lipases was also found in the recombinant lipaseas given in Figure1. This peptide is thought to play an important role in substrate recognition and binding (Tan and Miller, 1992).

\section{MGSSHHHHHHSSGLVPRGSHMASMTGGQQMGRGSEFMNYVSSGQGHAVLI I HGLFGNLDNLKGLGQVL ESQHQVIRVDVPNHGLSEHWDHMDYPRLAHAMI DLLDNLDIAHAHV IGHSMGGK IAMATALAF PERI I SMIAADIAPVAYEPRHDIVFAALESLPLEGHTDRRFALNHLINHGIDEATAQFLLKNLQRTDTGFRWK MNLSGLKTCYPNI I GWHNQP PNPVLSYSGPSLFIRGGDSNYVNSEHRDAIMAQFPTAQAKTLEGCGHW LHAQKPAIFNRIVSEFIDKQAM}

Figure 1 The recombinant Shewanella putrefaciens lipase amino acid sequence. The conserved sequence G-X-S-X-G in common lipases is indicated by the bold shadowed box.

The expression of recombinant lipase was observed by SDS-PAGE analysis. The SDS PAGE of bacterial lysate of E. coli strain BL21 (DE3) pLysS containing recombinant $\mathrm{pET} 28 \mathrm{a} / \mathrm{lipase}$ vector. The recombinant lipase is a monomeric protein with a predicted molecular weight of $29 \mathrm{kDa}$ (Fig.2).

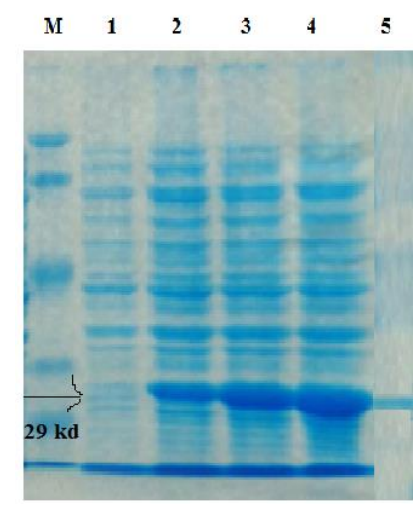

Figure 2 SDS-PAGE analysis: Marker is prestained protein molecular weight marker (Fermentas), First lane shows before IPTG induction. Second line shows after 1 hour IPTG induction, third line shows after 2 hours IPTG induction and fourth lane shows after 3 hours IPTG induction.Last one is purified enzyme.

\section{Biochemical characterization of recombinant lipase}

Effects of temperatures on enzymatic activity of recombinant lipase were measured in a temperature range between $30^{\circ} \mathrm{C}$ and $100^{\circ} \mathrm{C}$ when Tween 80 was used as the substrate. The obtained protein exhibited the maximum activity at 80 ${ }^{\circ} \mathrm{C}$ and the relative activity still reached to $50 \%$ even at $90{ }^{\circ} \mathrm{C}$ and $20 \%$ activity at 
$100{ }^{\circ} \mathrm{C}$. The enzyme was thermostable at $90{ }^{\circ} \mathrm{C}$ and $100{ }^{\circ} \mathrm{C}$ for 30 and for 20 minutes, respectively (Fig.3). According to the presently prevalent definition (Nakamura et al., 1992; Schmidt-Dannert et al., 1994), the obtained protein can be defined a thermophilic and thermostable enzyme. Among the studied thermostable lipases known so far, lipase from Aspergillus terreus showed excellent temperature tolerance $\left(15-90^{\circ} \mathrm{C}\right)$ and was able to retain $100 \%$ activity at $60^{\circ} \mathrm{C}$ for 24 hours, but it does not worked at higher temperatures (Yadav et al., 1998). Previously, a study showed that Pseudomonas sp. lipase was stable at $100{ }^{\circ} \mathrm{C}$ (Adams and Brawley, 1981). As far as our knowledge, there is no other lipase which shows any activity at $100{ }^{\circ} \mathrm{C}$. But, the obtained lipase from Shewanella putrefaciens was able to retain $20 \%$ of its activity even at $100{ }^{\circ} \mathrm{C}$ for 20 minutes.

To investigate the influence of $\mathrm{pH}$ on recombinant lipase, the activity was measured at various $\mathrm{pHs}$. The recombinant lipase was active in a $\mathrm{pH}$ range of 4.0-6.0, with the maximal activity at $\mathrm{pH} 5.0$ (Fig.3). The $\mathrm{pH}$ stability of lipase was explored by pre-incubating lipase in buffer with different $\mathrm{pH}$ at $80^{\circ} \mathrm{C}$ for $1 \mathrm{~h}$ The recombinant lipase completely lost its activity at $\mathrm{pH}$ 8.0. It retained approximately $70 \%$ of its activity at $\mathrm{pH} 4.0$ and 6.0 . But it retained only $30 \%$ of its activity at $\mathrm{pH}$ 7.0.
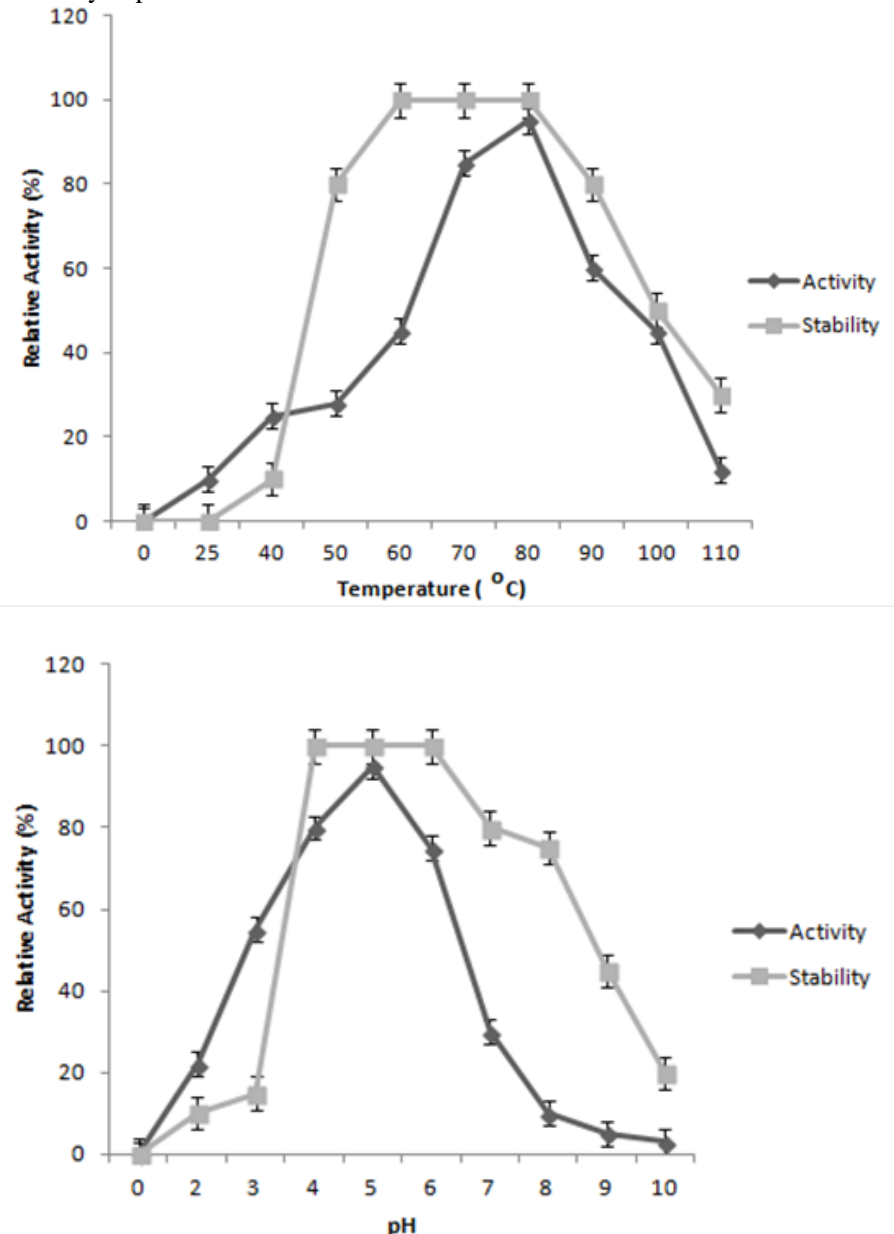

Figure 3 Effects of temperature and $\mathrm{pH}$ on the enzyme activity.Also it shows enzyme stability under different temperature and $\mathrm{pH}$ condition.

Metal ions play important roles in the structure and function of enzymes. Generally, metal ions might bind to some of the amino acid chains of protein and the enzyme activity can change by stabilizing or destabilizing its conformation (Ebrahimpour et al., 2011). The effect of some metal ions and chemical agents on the activity of recombinant lipase was investigated (Fig. 4). The effect of metal ions might be attributed to change in the solubility and behavior of ionized fatty acids upon complex formation with metal ions and the direct inhibition of enzyme catalytic function(Emtenani et al., 2013; Kambourova et al., 2003). Both of the tested metal ions $\mathrm{Ca}^{2+}$ and $\mathrm{Mn}^{2+}$ could meaningfully enhance the lipase activity but $\mathrm{Zn}^{2+}$ dramatically reduced the activity and also $\mathrm{Fe}^{2+} 10 \mathrm{mM}$ ions droped the enzyme activity. Other metal ions did not influence the lipase activity to much. Chemical agents such as EDTA did not affect the activity so this enzyme not a metalloenzyme (Sathish Yadav et al., 2011). Also presence of other chemical agents showed the same activity like EDTA.

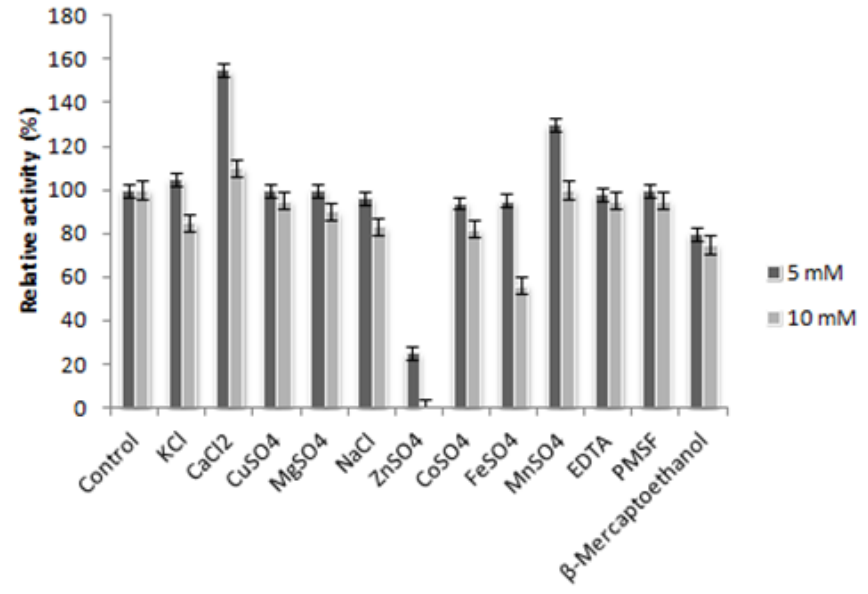

Figure 4 Effects of metal ions and chemical agents on the enzyme activity.

Recombinant lipase catalyzed biodiesel production in the presence of methanol and canola oil or waste oil. For complete conversion of oil to biodiesel, nearly 3 $\mathrm{M}$ of methanol need to be added into the reaction mixture. But in the transesterification system catalyzed by lipase, methanol usually is added stepwise, otherwise methanol could result in denaturation of lipase (Ranganathan et al., 2008). The production of high level at around $9 \mathrm{~h}$ and $15 \mathrm{~h}$ in order to waste oil or canola oil (Fig. 5) and our lipase showed a good biodiesel yield $\% 55$ and \% 65. Reaction stability remained up to $10 \mathrm{~h}$. We used 1:4 methanol in the reaction stepwise because in transesterification system using lipase, methanol is added stepwise due to inhibition of the lipase enzyme ( $\mathbf{L i}$ et al., 2011; Ranganathan et al., 2008).

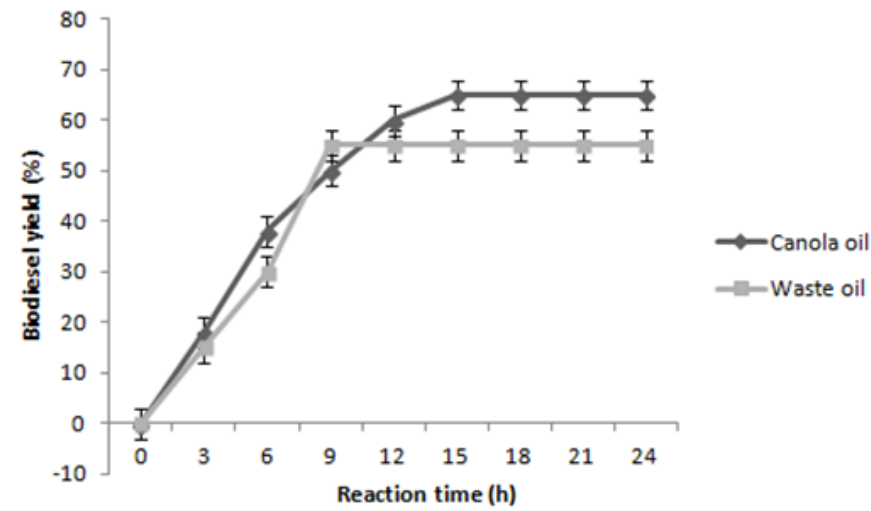

Figure 5 Biodiesel production using methanol from canola oil and waste oil by recombinant lipase.

\section{CONCLUSION}

In this study, we report the cloning of a novel lipase gene from Shewanella putrefaciens ATCC 8071. Biochemical characterization showed that the recombinant lipase was a novel thermostable lipase and possessed several attractive characteristics. The obtained lipase showed high activity in broad ranges of $\mathrm{pH}$ and temperature. Recombinant lipase is most active at $80{ }^{\circ} \mathrm{C}$ and even able to retain $50 \%$ and $20 \%$ activity at $90{ }^{\circ} \mathrm{C}$ and $100{ }^{\circ} \mathrm{C}$, respectively, which makes it different from other typical lipases. This lipase also catalys the biodiesel. These properties showed that it might be used for many biotechnological applications.

Acknowledgement: This study was supported by and Fatih University Research Project Foundation (P50091005_2 (1400).

\section{REFERENCES}

ADAMS, D., BRAWLEY, T. 1981. Factors influencing the heat resistance of a heat-resistant lipase of Pseudomonas. J. Food Sci. 46(3), 673-676. http://dx.doi.org/10.1111/j.1365-2621.1981.tb15321.x

ARAI, S., NAKASHIMA, K., TANINO, T., OGINO, C., KONDO, A. FUKUDA, H. 2010. Production of biodiesel fuel from soybean oil catalyzed by fungus whole-cell biocatalysts in ionic liquids. Enzyme Microb. Technol. 46(1), 51-55. http://dx.doi.org/10.1016/j.enzmictec.2009.08.008

BORNSCHEUER, U.T., BESSLER, C., SRINIVAS, R., HARI KRISHNA, S 2002. Optimizing lipases and related enzymes for efficient application. Trends Biotechnol. 20(10), 433-437. http://dx.doi.org/10.1016/s0167-7799(02)02046-2 
CARDENAS, F., ALVAREZ, E., DE CASTRO-ALVAREZ, M.-S., SANCHEZMONTERO, J.-M., VALMASEDA, M., ELSON, S.W., SINISTERRA, J.-V. 2001. Screening and catalytic activity in organic synthesis of novel fungal and yeast lipases. J. Mol. Catal. B: Enzym. 14(4), 111 123. http://dx.doi.org/10.1016/s1381-1177(00)00244-7

DIZGE, N., AYDINER, C., IMER, D.Y., BAYRAMOGLU, M., TANRISEVEN, A., KESKINLER, B. 2009. Biodiesel production from sunflower, soybean, and waste cooking oils by transesterification using lipase immobilized onto a novel microporous polymer. Bioresour. Technol. 100(6), 1983-1991. http://dx.doi.org/10.1016/j.biortech.2008.10.008

DWIARTI, L., ALI, E., PARK, E.Y. 2010. Enhancement of lipase catalyzed-fatty acid methyl esters production from waste activated bleaching earth by nullification of lipase inhibitors. Bioresour. Technol. 101(1), 14-20. http://dx.doi.org/10.1016/j.biortech.2009.08.032

EBRAHIMPOUR, A., RAHMAN, R.N.Z.R.A., BASRI, M., SALLEH, A.B 2011. High level expression and characterization of a novel thermostable, organic solvent tolerant, 1, 3-regioselective lipase from Geobacillus sp. strain ARM. Bioresour. Technol. 102(13), 6972-6981. http://dx.doi.org/10.1016/j.biortech.2011.03.083

EGGERT, T., VAN POUDEROYEN, G., PENCREAC'H, G., DOUCHET, I., VERGER, R., DIJKSTRA, B.W., JAEGER, K.-E. 2002. Biochemical properties and three-dimensional structures of two extracellular lipolytic enzymes from Bacillus subtilis. Colloids Surf., B 26(1), 37-46. http://dx.doi.org/10.1016/s09277765(02)00033-4

EMTENANI, S., ASOODEH, A., EMTENANI, S. 2013. Molecular cloning of a thermo-alkaliphilic lipase from Bacillus subtilis DR8806: Expression and biochemical characterization. Process Biochem. 48(11), 1679-1685. http://dx.doi.org/10.1016/j.procbio.2013.08.016

GUTARRA, M.L., GODOY, M.G., MAUGERI, F., RODRIGUES, M.I., FREIRE, D.M., CASTILHO, L.R. 2009. Production of an acidic and thermostable lipase of the mesophilic fungus Penicillium simplicissimum by solid-state fermentation. Bioresour. Technol. 100(21), 5249-5254. http://dx.doi.org/10.1016/j.biortech.2008.08.050

HAKI, G., RAKSHIT, S. 2003. Developments in industrially important thermostable enzymes: a review. Bioresour. Technol. 89(1), 17-34. http://dx.doi.org/10.1016/s0960-8524(03)00033-6

HASAN, F., SHAH, A.A., HAMEED, A. 2006. Industrial applications of microbial lipases. Enzyme Microb. Technol. 39(2), 235-251. http://dx.doi.org/10.1016/j.enzmictec.2005.10.016

KAMBOUROVA, M., KIRILOVA, N., MANDEVA, R., DEREKOVA, A. 2003. Purification and properties of thermostable lipase from a thermophilic Bacillus stearothermophilus MC 7. J. Mol. Catal. B: Enzym. 22(5), 307-313. http://dx.doi.org/10.1016/s1381-1177(03)00045-6

LI, Z., LI, X., WANG, Y., WANG, Y., WANG, F., JIANG, J. 2011. Expression and characterization of recombinant Rhizopus oryzae lipase for enzymatic biodiesel production. Bioresour. Technol. 102(20), 9810-9813. http://dx.doi.org/10.1016/j.biortech.2011.07.070

MHETRAS, N., BASTAWDE, K., GOKHALE, D. 2009. Purification and characterization of acidic lipase from Aspergillus niger NCIM 1207. Bioresour Technol. 100(3), 1486-1490. http://dx.doi.org/10.1016/j.biortech.2008.08.016

NAKAMURA, K., IIZUMI, T., OHTAKE, H., FUKASE, T. 1992. HyperProduction of Thermostable Lipase by Genetically Engineered Pseudomonas Species. in: Biochem. Eng. for 2001, Springer, pp. 173-175. http://dx.doi.org/10.1007/978-4-431-68180-9 44

RANGANATHAN, S.V., NARASIMHAN, S.L., MUTHUKUMAR, K. 2008. An overview of enzymatic production of biodiesel. Bioresour. Technol. 99(10), 3975-3981. http://dx.doi.org/10.1016/j.biortech.2007.04.060

RASHID, N., SHIMADA, Y., EZAKI, S., ATOMI, H., IMANAKA, T. 2001. Low-temperature lipase from psychrotrophic Pseudomonas sp. strain KB700A. Appl. Environ. $\quad$ Microbiol. $\quad 67(9), \quad 4064-4069$. http://dx.doi.org/10.1128/aem.67.9.4064-4069.2001

SATHISH YADAV, K., ADSUL, M., BASTAWDE, K., JADHAV, D. THULASIRAM, H., GOKHALE, D. 2011. Differential induction, purification and characterization of cold active lipase from Yarrowia lipolytica NCIM 3639 $\begin{array}{llll}\text { Bioresour. } & \text { Technol. 102(22), } & \text { 10663-10670. }\end{array}$ http://dx.doi.org/10.1016/j.biortech.2011.09.013

SCHMID, R.D., VERGER, R. 1998. Lipases: interfacial enzymes with attractive applications. Angew. Chem. Int. Ed. 37(12), 1608-1633. http://dx.doi.org/10.1002/chin.199836344

SCHMIDT-DANNERT, C., SZTAJER, H., STÖCKLEIN, W., MENGE, U., SCHMID, R.D. 1994. Screening, purification and properties of a thermophilic lipase from Bacillus thermocatenulatus. Biochim. Biophys. Acta 1214(1), 43-53. http://dx.doi.org/10.1016/0005-2760(94)90008-6

SHI, B., ZENG, L., SONG, H., SHI, Q., WU, S. 2010. Cloning and expression of Aspergillus tamarii FS132 lipase gene in Pichia pastoris. Int. J. Mol. Sci. 11(6), 2373-2382. http://dx.doi.org/10.3390/ijms11062373

SHIBATANI, T., OMORI, K., AKATSUKA, H., KAWAI, E., MATSUMAE, H. 2000. Enzymatic resolution of diltiazem intermediate by Serratia marcescens lipase: molecular mechanism of lipase secretion and its industrial application. $J$.
Mol. Catal. B: Enzym. 10(1), 141-149. http://dx.doi.org/10.1016/s13811177(00)00122-3

SINIRLIOGLU, Z.A., SINIRLIOGLU, D., AKBAS, F. 2013. Preparation and characterization of stable cross-linked enzyme aggregates of novel laccase enzyme from Shewanella putrefaciens and using malachite green decolorization. $\begin{array}{llll}\text { Bioresour. } & \text { Technol. } & \text { 146, } & \text { 807-811. }\end{array}$ http://dx.doi.org/10.1016/j.biortech.2013.08.032

TAN, Y., MILLER, K. 1992. Cloning, expression, and nucleotide sequence of a lipase gene from Pseudomonas fluorescens B52. Appl. Environ. Microbiol. 58(4), 1402-1407.

YADAV, R.P., SAXENA, R.K., GUPTA, R., DAVIDSON, W. 1998 Purification and characterization of a regiospecific lipase from Aspergillus terreus. Biotechnol. Appl. Biochem. 28(3), 243-249.

YAN, J., YAN, Y., LIU, S., HU, J., WANG, G. 2011. Preparation of cross-linked lipase-coated micro-crystals for biodiesel production from waste cooking oil. $\begin{array}{llll}\text { Bioresour. } & \text { Technol. } & \text { 102(7), } & \text { 4755-4758. }\end{array}$ http://dx.doi.org/10.1016/j.biortech.2011.01.006

YUMOTO, I., HIROTA, K., SOGABE, Y., NODASAKA, Y., YOKOTA, Y. HOSHINO, T. 2003. Psychrobacter okhotskensis sp. nov., a lipase-producing facultative psychrophile isolated from the coast of the Okhotsk Sea. Int. J. Syst. Evol. Micr. 53(6), 1985-1989 http://dx.doi.org/10.1099/ijs.0.02686-0 .

ZHU, C., CHEN, Z., YU, G. 2012. Fungicidal mechanism of chlorine dioxide on Saccharomyces cerevisiae. Ann. Microbiol. 63:495-502.http: //dx. doi.org/ 10.1007/s13213-012-0494-8 